\title{
Evaluation of Association Between the Serum Levels of MMP-9 and MMP-9/TIMPs With Soluble Forms of Selectins and Itching Induced by Sulfur Mustard
}

\author{
Nayere Askari'; Tooba Ghazanfari ${ }^{2 *}$; Mohammad Mehdi Naghizadeh²; Athar Moin²; Ali \\ Khamesipour $^{3}$; Shahryar Pourfarzam²; Zuhair Mohammad Hassan ${ }^{4}$ \\ 1. Dept. of Biology, Faculty of Basic Sciences, Shahid Bahonar University of Kerman, Kerman, Iran \\ 2. Immunoregulation Research Center, Shahed University, Tehran, Iran \\ 3. Center for Research and Training in Skin Diseases and Leprosy, Tehran University of Medical Sciences, Tehran, Iran \\ 4. Dept. of Immunology, Tarbiat Moddares University, Tehran, Iran
}

\begin{tabular}{c} 
KEYWORDS \\
\hline Mustard Gas \\
Pruritus \\
MMP-9 \\
MMP-9/TIMPs \\
Selectins \\
\end{tabular}

Article Info

Received 08 Feb 2016;

Accepted 25 Oct 2016;

Published Online 27 Jan 2017;

\section{ABSTRACT}

Background \& objective: Pruritus is the most frequent chronic dermal complication of sulfur mustard (SM), which negatively influences the quality of life. Exact pathophysiology of SM-induced itching is unknown. The current study aimed at evaluating the possible association between SM-induced itching and the serum levels of matrix metalloproteinase (MMP)-9 and their endogenous inhibitors, and serum levels of soluble forms of selectins (sL-, sP-, and sE-selectins) as adhesion molecules involved in the development of different inflammatory reactions.

Methods: Serum levels of MMP-9, MMP-9/ tissue inhibitors of metalloproteinases (TIMPs), and selectins were measured by the enzyme-linked immunosorbent assay (ELISA), and compared between the groups $(n=368)$ with and without itching, and matched control groups $(n=126)$.

Results: Serum levels of MMP-9 were significantly higher in the SM exposed group with itching, compared with that of the group without itching (medians: 894 and $624 \mathrm{pg} / \mathrm{mL}$ respectively; P-value $=0.034$ ). There was no relationship between the serum levels of MMP-9/TIMP-1, MMP-9/TIMP-2, MMP-9/TIMP-4, and itching in the patients exposed to SM. Median serum levels of sE- and sL-selectins in the exposed group with itching were higher than those of the exposed group without itching. These differences were statistically insignificant (P-values $=0.084$ and 0.095 , respectively).

Conclusion: According to the results of the current study, the increased serum levels of MMP-9 and selectins 20 years after exposure may play role in the pathogenesis and persistence of SM-induced itching in the exposed individuals.

Corresponding Information: Tooba Ghazanfari, Immunoregulation Research Center, Shahed University, Tehran, I.R Iran. Tel: +98-2188964792, Fax: +98-2188966310, E-mail: tghazanfari@yahoo.com; ghazanfari@shahed.ac.ir

Copyright $\odot$ 2017, IRANIAN JOURNAL OF PATHOLOGY. This is an open-access article distributed under the terms of the Creative Commons Attribution-noncommercial 4.0 International License which permits copy and redistribute the material just in noncommercial usages, provided the original work is properly cited.

\section{Introduction}

Exposure to sulfur mustard (SM) leads to shortand long-term adverse effects in various organs including the skin. Skin is the first and most heavily damaged organ upon SM exposure. In Sardasht-Iran Cohort study (SICS), the most common skin symptom was pruritus and the difference between the exposed and control groups was statistically significant (1). The prevalence of itching in the studies by Moin et al. (1), Fekri and Janghorbani (2), Toosi et al. (3), Hefazi et al. (4), and Heidari et al., (5) was $94.7 \%, 54.8 \%, 75.1 \%, 65 \%$, and $25.6 \%$, respectively. In addition, pruritus can significantly impair patients' quality of life (6-8). Exact pathophysiology of SM-induced itching is unknown. Drugs are used symptomatically based on individual cases (9). Chronic itch represents a burdensome clinical problem that can be resulted from various etiologies (10). The neurophysiology of pruritus is not fully understood. However, it is known that $\mathrm{A} \delta$ and $\mathrm{C}$ fibres are responsible for transmission of pruritus (11). There are numerous mediators capable of stimulating these afferent nerves resulting in itch, including biogenic amines, proteases, cytokines, and peptides (10). Inflammation is a key component in the pathogenesis of SM-induced skin complications (12). 
Cytokines and chemokines are inflammatory mediators and important activators of sensory nerves, thereby contributing to neurogenic inflammation, pain, and pruritus (13). Various studies revealed the role of selected matrix metalloproteinases (MMPs) in pathogenesis of several skin diseases such as dermatitis herpetiformis (14), atopic dermatitis (15), and systemic scleroderma (16). Several MMPs were previously reported to have elevated in psoriatic lesions $(17,18)$. MMPs hydrolyze most components of the extracellular matrix. The activities of MMPs are also controlled by natural tissue inhibitors of metalloproteinases (TIMPs). These proteinases play a central role in various biological processes, including normal tissue remodeling, wound healing, and angiogenesis (19).

In addition, adhesion molecules appear to play a role in the occurrence and development of pruritus, at least in certain dermatologic disorders. For example, selectins play a key role in the pathogenesis of common inflammatory skin disorders such as atopic dermatitis and psoriasis (20-22).

The role of MMPs and selectins in Skin SM induced disorders is poorly understood. To clarify the mechanisms and possible mediators involved in the pruritus in the patients exposed to SM, the present study aimed at assessing the serum levels of soluble forms of selectins (L, P, and E), MMP-9, and MMP9/TIMPs complex in the SM exposed and matched control groups.

\section{Materials and Methods}

\section{Study Design and Participant}

The current study was a part of SICS and the details of methodology were previously reported (23). Briefly, 368 male subjects aged 20 to 60 years exposed to SM about 20 years ago, and 126 age/gender-matched unexposed volunteers were included in the cohort. SICS was initiated in 2006 and the clinical evaluation and sample collection were done in June 2007 and the experiments were completed in six months. Clinical evaluation was performed on each volunteer participant; every volunteer was interviewed and physically examined by a dermatologist. Patients exposed to SM had multiple organ complications and were categorized into subgroups to make easier understanding of any possible relationship between serum levels of MMP9, MMP-9/TIMPs, and selectins with skin itching. In the current study, with respect to itching, the participants were divided into four groups as follows:

1) Patients exposed to SM with skin itching, 2) Patients exposed to SM without skin itching, 3) The control group with skin itching, and 4) The control group without skin itching.

\section{Ethical Considerations}

The study was approved by the Ethical Committee Board of Research Ethics of Janbazan Medical and Engineering Research Center (JMERC), and Board of Research, Iranian Ministry of Health and Medical Education, and Ethical committee of Shahed University. Potential volunteers were informed about the purpose and procedure of the study; the volunteers who signed an informed consent were recruited.

\section{Serum Collection}

Peripheral blood samples were drawn into vacutainer tubes (BD Biosciences). The sera were separated by centrifugation at $2000 \times \mathrm{g}$ at $4{ }^{\circ} \mathrm{C}$ for 20 minutes and stored at $-80^{\circ} \mathrm{C}$ until laboratory measurements.

\section{Enzyme-linked Immunosorbent Assay Measurements}

Human MMP-9, MMP-9-TIMPs complex DuoSet ${ }^{\circledR}$ ELISA Development Kits (R\&D Systems) were used to measure the components in the sera. Human sL-selectin/CD62L, sE-selectin/CD62E, and sP-selectin/CD62P Quantikine ${ }^{\circledR}$ ELISA kits (R\&D Systems) were used to measure the selectin levels in the sera according to the manufacturer's instruction. This assay employs the quantitative sandwich enzyme immunoassay technique. The ELISA reader and washer were Stat-Fax 2100 and Stat-Fax 2600 (USA), respectively.

\section{Statistical Analysis}

Statistical comparison among groups was performed using Mann-Whitney test. Differences were considered statistically significant at $\mathrm{P} \leq 0.05$. Data were presented as mean (standard deviation) and median (first and third quartiles). Analysis of all the 
data was performed using SPSS software version 16.0 (Chicago, Illinois, USA).

\section{Results}

In SICS study, 94.7\% $(n=338)$ of the exposed group and $63.3 \%(n=81)$ of unexposed control group had skin itching. There was a statistically significant difference between the exposed and matched control groups in terms of itching ( $\mathrm{P}$-value $<0.001$ ).

Comparison of the serum levels of MMP-9, MMP-9/TIMP-1, MMP-9/TIMP-2 and MMP9/TIMP-4 between the patients exposed to SM with or without itching and the matched controls

Median serum levels of MMP-9 were $624 \mathrm{ng} / \mathrm{mL}$ in the exposed group without itching and $894 \mathrm{ng} / \mathrm{mL}$ in the exposed group with itching, $855 \mathrm{ng} / \mathrm{mL}$ in the control group with itching, and $848 \mathrm{ng} / \mathrm{mL}$ in the control group without itching. The difference between the exposed groups with and without itching was statistically significant $(\mathrm{P}$-value $=0.034)($ Table 1$)$.

As shown in tables 2, 3, and 4 there were no significant differences among the serum levels of MMP-9/TIMP-1, MMP-9/TIMP-2, and MMP9/TIMP-4 between the exposed groups with without itching.

A significant increase in MMP-9/TIMP-2 complex was observed in the control group with itching compared to the control group without itching ( $\mathrm{P}$ value $<0.008)$. Also, there was a significant difference between the SM-exposed group with itching and the control group $(\mathrm{P}-\mathrm{value}=0.019)($ Table 3$)$.

Table 1. MMP-9 in the Control and Sulfur Mustard Exposed Groups With Itching

\begin{tabular}{cccccccccc}
\hline & \multicolumn{1}{c}{ MMP-9 Serum $(\boldsymbol{\mu g} / \mathbf{m L})$} \\
\hline Study groups & Itching & $\mathrm{N}$ & Mean & SD & Median & $\mathrm{Q}_{1}$ & $\mathrm{Q}_{3}$ & P-value $^{1}$ & P-value $^{2}$ \\
Control & No & 45 & 1.221 & 0.926 & 0.848 & 0.543 & 1.694 & 0.902 & 0.196 \\
& Yes & 78 & 1.025 & 0.599 & 0.855 & 0.630 & 1.179 & 0.315 \\
SM-Exposed & No & 20 & 0.889 & 0.642 & 0.624 & 0.465 & 1.231 & 0.034 \\
& Yes & 320 & 1.772 & 2.357 & 0.894 & 0.646 & 1.718 & & \\
\hline
\end{tabular}

The serum levels of MMP-9 in volunteers with and without itching were assessed and a comparison was made between the control and exposed groups, and within each groups.

$\mathrm{P}_{\text {-value }}{ }^{1}$ : Comparison of the serum level between participants with and without itching within each group (Mann-Whitney test).

P-value ${ }^{2}$ : Comparison between the exposed groups and control groups (Mann-Whitney test). Bold data shows significant differences (P-value <0.05).

Table 2. MMP-9/TIMP-1 Complex in the Control and Sulfur Mustard Exposed Groups With Itching

\begin{tabular}{|c|c|c|c|c|c|c|c|c|c|}
\hline \multicolumn{10}{|c|}{ MMP-9/TIMP-1 Serum $(\mu \mathrm{g} / \mathrm{mL})$} \\
\hline Study Groups & Itching & $\mathrm{N}$ & Mean & SD & Median & $\mathrm{Q}_{1}$ & $\mathrm{Q}_{3}$ & P-value ${ }^{1}$ & $\mathrm{P}$-value ${ }^{2}$ \\
\hline \multirow{2}{*}{ control } & No & 45 & 35.157 & 43.506 & 18.552 & 9.610 & 51.886 & 0.607 & 0.909 \\
\hline & Yes & 76 & 27.324 & 28.195 & 18.049 & 7.781 & 32.094 & & 0.272 \\
\hline \multirow{2}{*}{ Exposed } & No & 20 & 32.327 & 34.651 & 16.546 & 1.1017 & 37.834 & 0.850 & \\
\hline & Yes & 317 & 32.263 & 41.168 & 20.646 & 10.032 & 39.898 & & \\
\hline
\end{tabular}

P-value2: Comparison between exposed subjects and corresponding controls (Mann-Whitney test). Bold data shows significant differences at $\mathrm{P}$-value $<0.05$.

Table 3. MMP-9/TIMP-2 Complex in the Control and Sulfur Mustard Exposed Groups With Itching

\begin{tabular}{|c|c|c|c|c|c|c|c|c|c|}
\hline \multicolumn{10}{|c|}{ MMP-9/TIMP-2 Serum $(\mu \mathrm{g} / \mathrm{mL})$} \\
\hline Study Groups & Itching & $\mathrm{N}$ & Mean & SD & Median & $\mathrm{Q}_{1}$ & $\mathrm{Q}_{3}$ & P-value ${ }^{1}$ & P-value ${ }^{2}$ \\
\hline \multirow[t]{2}{*}{ Control } & No & 42 & 2.256 & 9.174 & 0.023 & 0.00 & 0.196 & 0.008 & 0.019 \\
\hline & Yes & 78 & 2.935 & 16.726 & 0.246 & 0.041 & 0.844 & & 0.859 \\
\hline \multirow[t]{2}{*}{ SM-Exposed } & No & 20 & 1.343 & 2.919 & 0.439 & 0.00 & 1.194 & 0.272 & \\
\hline & Yes & 316 & 1.681 & 10.520 & 0.271 & 0.00 & 0.682 & & \\
\hline
\end{tabular}

The serum levels of MMP-9/TIMP-2 complex in volunteers with and without itching were assessed and a comparison was made between the control and exposed groups, and within each group.

P-value $^{1}$ : Comparison between participants with and without itching within each group (Mann-Whitney test).

P-value ${ }^{2}$ : Comparison between exposed subjects and corresponding controls (Mann-Whitney test). Bold data shows

significant differences at $\mathrm{P}$-value $<0.05$ 
A significant increase was observed in MMP9/TIMP-4 complex in the exposed group without itching, compared with the matched control group (P-value $<0.034)$ (Table 4).

Table 4. MMP-9/TIMP-4 complex (Serum) in control and exposed groups With itching

\begin{tabular}{ccccccccccc}
\hline \multirow{2}{*}{ Study Groups } & Itching & N & Mean & SD & Median & $Q_{1}$ & $Q_{3}$ & P-value $^{1}$ & P-value $^{2}$ \\
\hline \multirow{2}{*}{ Control } & No & 44 & 58.067 & 133.495 & 18.834 & 15.031 & 26.072 & 0.164 & 0.034 \\
& Yes & 76 & 89.335 & 229.037 & 21.042 & 15.667 & 40.491 & - & 0.550 \\
\hline \multirow{2}{*}{ Exposed } & No & 20 & 108.807 & 347.044 & 24.816 & 21.042 & 37.347 & 0.467 & - \\
\cline { 2 - 11 } & Yes & 315 & 86.626 & 255.396 & 24.502 & 16.302 & 40.79 & - & - \\
\hline
\end{tabular}

The serum levels of MMP-9/TIMP-4 complex in volunteers with and without itching were assessed and a comparison was made between the control and exposed groups, and within each group.

$\mathrm{P}_{\text {-value }}{ }^{1}$ : Comparison of the serum level between participants with and without itching within each group (Mann-Whitney test).

P-value ${ }^{2}$ : Comparison between the patients exposed to SM and the corresponding controls (Mann-Whitney test). Bold data shows the significant differences at $\mathrm{P}$-value $<0.05$.

Table 5. sE-Selectin in the Control and Sulfur Mustard Exposed Groups With Itching

\begin{tabular}{|c|c|c|c|c|c|c|c|c|c|c|}
\hline \multirow[b]{2}{*}{ Study Groups } & \multirow{2}{*}{ Itching } & \multicolumn{6}{|c|}{ SE-Selectin $(p g / m L)$} & \multirow{2}{*}{ P-value ${ }^{1}$} & \multirow[b]{2}{*}{ P-value ${ }^{2}$} & \multirow[b]{2}{*}{ P-value } \\
\hline & & $\mathrm{N}$ & Median & Q1 & Q3 & Mean & SD & & & \\
\hline \multirow{2}{*}{ Control } & No & 45 & 23.88 & 11.81 & 28.44 & 22 & 12.435 & \multirow{2}{*}{0.150} & 0.909 & \multirow{4}{*}{0.004} \\
\hline & Yes & 77 & 24.57 & 17.01 & 32.82 & 26.587 & 14.925 & & 0.124 & \\
\hline \multirow{2}{*}{ SM-Exposed } & No & 20 & 21.695 & 10.2 & 31.83 & 23.94 & 15.869 & \multirow{2}{*}{0.084} & - & \\
\hline & Yes & 319 & 26.56 & 17.33 & 40.09 & 30.483 & 17.685 & & - & \\
\hline
\end{tabular}

The serum levels of sE-Selectin in volunteers with and without itching were assessed and a comparison was made between the control and SM-exposed groups, and within each group.

P-value : Comparison between with and without itching within each group (Mann-Whitney test).

$\mathrm{P}_{-v^{2}}$ alue ${ }^{2}$ : Comparison of the SM-exposed groups with the corresponding controls (Mann-Whitney test).

P-value ${ }^{3}$ : Comparison between the SM-exposed group with itching and the control group without itching (Mann-Whitney test). Bold data shows significant differences at $\mathrm{P}$-value $<0.05$.

Table 6. sL-Selectin in Control and Sulfur Mustard Exposed Groups With Itching

\begin{tabular}{|c|c|c|c|c|c|c|c|c|c|}
\hline \multirow{2}{*}{ Study Groups } & \multirow{2}{*}{ Itching } & \multicolumn{6}{|c|}{ SL-Selectin(pg/mL) } & \multirow{2}{*}{ P-value ${ }^{1}$} & \multirow{2}{*}{ P-value ${ }^{2}$} \\
\hline & & $\mathrm{N}$ & Median & Q1 & Q3 & Mean & SD & & \\
\hline \multirow{2}{*}{ Control } & No & 45 & 12.360 & 9.547 & 13.850 & 11.919 & 3.134 & \multirow{2}{*}{0.791} & 0.082 \\
\hline & Yes & 77 & 11.820 & 10.140 & 13.750 & 12.203 & 2.98 & & 0.062 \\
\hline \multirow{2}{*}{ Exposed } & No & 20 & 9.561 & 8.314 & 11.815 & 10.496 & 2.837 & \multirow{2}{*}{0.095} & \\
\hline & Yes & 318 & 11.330 & 9.180 & 13.410 & 11.508 & 3.095 & & \\
\hline
\end{tabular}

The serum levels of sL-Selectin in volunteers with and without itching were assessed and a comparison was made between the control and SM-exposed groups, and within each group.

P-value ${ }^{1}$ : Comparison between the participants with and without itching within each group (Mann-Whitney test).

$\mathrm{P}_{\text {-value }}^{2}$ : Comparison of the SM-exposed subjects with the corresponding controls (Mann-Whitney test). Bold data shows significant differences at $\mathrm{P}$-value $<0.05$.

Comparison of the Serum levels of sE-, sL-, and sP-selectins between the patients exposed to SM with or without itching and the matched controls

Median serum levels of sE-selectin in the exposed group with itching $(26.56 \mathrm{pg} / \mathrm{mL})$ were higher than those of the SM-exposed group without itching $(21.695 \mathrm{pg} / \mathrm{mL})$. This difference was statistically insignificant $(\mathrm{P}$-value $=0.084)$. There was no significant difference between the serum levels of sE-selectin in the SM-exposed groups without itching and the matched control groups (Table 5).
A significant increase in sE-selectin was observed between the SM-exposed group with itching and the control group without itching ( $\mathrm{P}$ value $<0.004)$. As illustrated in Table 6 , the serum levels of sL-selectin was lower in the SM-exposed group without itching compared with those of the SM-exposed group with itching (9.561 vs. 11.33 $\mathrm{pg} / \mathrm{mL}$, respectively).

The difference was statistically insignificant (P-value $=0.095)$. Also, there was a difference between the subjects exposed to SM without itching and the matched controls, but this difference was statistically insignificant (P-value 
$=0.082$ ). As indicated in Table 7, the serum levels of sP-selectin were significantly lower in the SMexposed group with and without itching, compared with their matched control groups (144.22 vs. $152.32 \mathrm{pg} / \mathrm{mL}, \mathrm{P}$-value $=0.013$ for with itching and
126.67 vs. 163.3 , P-value $<0.031$ for without itching groups). The difference between the SMexposed groups with and without itching was statistically insignificant (Table 7).

Table 7. sP-Selectin in the Control and Sulfur Mustard Exposed Groups With Itching

\begin{tabular}{|c|c|c|c|c|c|c|c|c|c|}
\hline \multirow{2}{*}{ Study Groups } & \multirow{2}{*}{ Itching } & \multicolumn{6}{|c|}{ SP-Selectin $(\mathrm{pg} / \mathrm{mL})$} & \multirow[b]{2}{*}{ P-value ${ }^{1}$} & \multirow[b]{2}{*}{ P-value ${ }^{2}$} \\
\hline & & $\mathrm{N}$ & Median & Q1 & Q3 & Mean & SD & & \\
\hline \multirow{2}{*}{ Control } & No & 45 & 163.3 & 128.9 & 204 & 167.632 & 55.18 & 0.779 & 0.031 \\
\hline & Yes & 77 & 152.32 & 126.88 & 217.6 & 173.286 & 60.718 & & 0.013 \\
\hline \multirow{2}{*}{ Exposed } & No & 20 & 126.67 & 83.83 & 173.29 & 134.957 & 55.698 & 0.147 & \\
\hline & Yes & 319 & 144.22 & 116.52 & 178.34 & 152.299 & 50.134 & & \\
\hline
\end{tabular}

The serum levels of sP-Selectin in volunteers with and without itching were assessed and a comparison was made between the control and SM-exposed groups, and within each group.

P-value ${ }^{1}$ : Comparison between the participants with and without within each group (Mann-Whitney test).

$\mathrm{P}_{\text {-value }}^{2}$ : Comparison of the subjected exposed to SM with the corresponding controls (Mann-Whitney test). Bold data shows significant differences at $\mathrm{P}$-value $<0.05$.

\section{Discussion}

Exposure to SM leads to many delayed skin complications including itching. In SICS, the incidence of itching was reported $94.7 \%$ in the SM-exposed group, 20 years after the exposure. Exact pathophysiology of SM-induced itching is unknown.

The current study found that even after a long post-exposure period in the patients exposed to SM, an increased serum level of MMP-9 was associated with the itching. According to the obtained results, it is suggested that the SMexposed group without itching could have overcome the SM-induced changes that cause itching through decrease in MMP-9, and in fact this effect is compensatory, whereas, in the SMexposed subjects with itching, MMP-9 levels were not significantly different from in the ones in the control groups.

The serum levels of MMP-9/TIMP-2, and MMP-9/TIMP-4 were different between the SMexposed individuals and the control ones, regardless of skin itching. However, the current study results did not show significant association between the serum levels of MMP-9/TIMP-2 and MMP-9/TIMP-4 with itching in the patients exposed to SM. In the unexposed subjects with itching, the study results did not show any significant differences in the serum levels of MMP-9, compared with those of the healthy controls, but increase in MMP-9/TIMP2 remained significantly in association with itching.

The data suggested that MMP-9 contributed to itching in both groups; in the SM-exposed group with different expression of $M M P-9$ and in the unexposed group with an imbalance between active MMP-9 and TIMP-2. Overexpression and activation of $M M P s$, or an imbalance between active MMPs and TIMPs were suggested as key factors involved in the breakdown of extracellular matrix found in a number of the disease states (2426).

The mean level of MMP-9 in the serum of dry skin patients exposed to SM showed significant increase, compared with that of the normal individuals (27). Previous studies showed that the average amount of MMP-8 and -9, and TIMP-1 and -2 in the skin tissue sample of the mustard gas exposed victims was significantly higher than that of the normal individuals (28). Shakarjian et al., demonstrated the significant increase in the expression of MMP-9 in mouse skin after SM exposure (29). MMP-9 expression was also observed in inflammation cells and perilesional skin in bullous pemphigoid diseases, which pathologically resemble SM-induced skin lesion (30).

Epidermal hyper innervation observed in the dermatoses with intractable pruritus, such as atopic dermatitis, suggested that the hyper innervation was partially responsible for abnormal itch perception $(31,32)$. Neuronal MMPs also play a role in the penetration of nerve fibres into the extracellular matrix (33). The role of MMPs in SM-induced itching is poorly understood and further studies should be conducted to discover the meaning of the differential expression of MMP-9 gene in the exposed patients with itching. 
In addition, an increased serum concentration of E- and L-selectins was found in the subjects exposed to SM with itching. The difference between the patients exposed to SM with and without itching were at the borderline level of significance (P-values $=0.084$ and 0.095, respectively, for E- and L-selectins). It was also shown that the level of E-selectin in the SMexposed group with itching was significantly higher than that of the normal control group.

Unfortunately, there are currently limited data on the possible role of adhesion molecules in SMinduced skin disorders and pruritus, but various eye, skin, and lung diseases are also associated with the induction of soluble selectins (34-36). Atopic dermatitis (AD) is a chronic inflammatory skin disease characterized by an intensely pruritic skin rash (37). Gutge sell et al,. reported a statistically significant positive correlation between $\mathrm{sE}$-selectin and disease activity in atopic dermatitis (21). Skin biopsies from inflamed skin of the patients with $\mathrm{AD}$ showed that upregulation of endothelial cell expression of $P$ - and E-selectin (38), and the immunological changes in the patients with $\mathrm{AD}$ treated with cyclosporine included eosinophil count reduction and lower levels of E-selectin (39). Shimada et al., suggested that the elevated sL-selectin levels and abnormal L-selectin expression on some leukocyte subsets in patients with $\mathrm{AD}$ had correlations with $\mathrm{AD}$ associated inflammation and that the serum level of sL-selectin was a serologic indicator of disease severity in $\mathrm{AD}$ (40). Lesional skin biopsies from patients with pruritus in psoriasis vulgaris showed overexpression of E-selectin on vascular endothelial cells. A significant correlation was observed between the severity of pruritus and the density of E-selectin immune reactive vessels (41). Due to their involvement in the pathogenesis of various local and systemic inflammatory disorders, selectins are now considered as potential diagnostic and therapeutic tools (42).

\section{Conclusion}

The current study concluded that increased serum levels of MMP-9 and selectins 20 years after exposure to SM may have roles in pathogenesis and persistence of SM-induced itching in the exposed individuals. The mechanism of skin SM-induced itching is poorly understood. However, the similarities in altered MMP-9 and selectins levels between the patients exposed to $\mathrm{SM}$ with itching and other associated pathological complications could enable clinicians to understand the disease process and make better therapeutic decisions. It seems that further research is required to clarify the role of immunological parameters in the pathogenesis of SM-induced itching. However, it should be noted that exposure to SM causes alterations in the expression of various parameters of immune responses, and on the other hand, increase and decrease of SM induced immune mediators may cause disorders, whereas, some of them are considered as compensatory responses to prevent disorders. Therefore, it seems that the multifactorial mechanism of itching and achieving the desired results should be investigated further.

\section{Acknowledgements}

The current study was conducted by the Immuno regulation Research Center of Shahed University and Janbazan Medical and Engineering Research Center (JMERC), Tehran, Iran. Authors would like to thank all the participants.

\section{Funding/Support}

The research was financially supported by the Iranian Foundation of Martyr and Veterans Affairs and Ministry of Health and Medical Education.

\section{Declaration of interest}

The authors declared no conflict of interest.

\section{References}

1. Moin A, Ghazanfari T, Davoudi SM, Emadi N, Panahi Y, Hassan ZM, et al. Long-term skin findings of sulfur mustard exposure on the civilians of Sardasht, Iran. Toxin Reviews. 2009;28(1):24-9.

2. Fekri A. Late cutaneous complications in chemical warfare victims in Kerman province. Journal of Kerman University of Medical Sciences. 1995;2(3):108-19.

3. Toosi P, Amir jA, Heydarian M, Keshvarz S, Fayaz M. Delayed Cutaneous complications in soldiers attacked by chemical agents. Pejouhandeh. 2002;7:209-12.

4. Hefazi M, Maleki M, Mahmoudi M, Tabatabaee A, Balali-Mood M. Delayed complications of sulfur mustard poisoning in the skin and the immune system of Iranian veterans 16-20 years after exposure. International journal of dermatology. 2006;45(9):102531. 
5. Heidari M, Karaminejad Ranjbar M, Ansari H. Prevalence of late toxic complication in chemical warfare victims. Daneshvar Medicine, Scientific Research Journal of Shahed University. 1999;7:67-72.

6. Greaves M. Pruritus. In: Bolognia JL, Jorizzo J, Rapini R, eds. Dermatology Edinburgh: Mosby. 2003:pp. 85-90.

7. William J, Berger T, Elston D. Andrews' diseases of the skin. 10 ed.: Philadelphia: WB Saunders; 2006.

8. Norton $\mathrm{S}$. The skin in bioterrorism and biologic warfare. In: Wolff K, Goldsmith LA, Katz SI, Glchrest BA, Paller AS, Leffell DJ, eds. 7th ed.: New York: McGraw Hill; 2008.

9. Lateef F. Of pruritus and terrorism. Singapore Med J. 2007;48(5):380-2.

10. Potenzieri C, Undem BJ. Basic mechanisms of itch. Clin Exp Allergy. 2012;42(1):8-19.

11. Heyl T. Brachioradial pruritus. Archives of dermatology. 1983;119(2):115-6.

12. Moin A, Khamesipour A, Hassan ZM, Ebtekar M, Davoudi SM, Vaez-Mahdavi MR, et al. Pro-inflammatory cytokines among individuals with skin findings long-term after sulfur mustard exposure: Sardasht-Iran Cohort Study. Int Immunopharmacol. 2013;17(3):986-90.

13. Roosterman D, Goerge T, Schneider SW, Bunnett NW, Steinhoff M. Neuronal control of skin function: the skin as a neuroimmunoendocrine organ. Physiological reviews. 2006;86(4):1309-79.

14. Dziankowska-Bartkowiak B, Waszczykowska E, Żebrowska A. The role of metaloproteinases and their inhibitors in the patomechanism of skin diseases. Alerg Astma Immun. 2004;9:71-9.

15. Groneberg D, Bester C, Grützkau A, Serowka F, Fischer A, Henz B, et al. Mast cells and vasculature in atopic dermatitis-potential stimulus of neoangiogenesis. Allergy. 2005;60(1):90-7.

16. Fakhoury H, Hillarby M, Weiss J. Increased gelatinase activity in systemic sclerosis dermal fibroblast cultures with unaltered gelatinase A mRNA expression. Journal of dermatological science. 2002;29(1):62-9.

17. Suomela S, Kariniemi AL, Snellman E, Saarialho-Kere U. Metalloelastase (MMP-12) and 92$\mathrm{kDa}$ gelatinase (MMP-9) as well as their inhibitors, TIMP-1 and-3, are expressed in psoriatic lesions. Experimental dermatology. 2001;10(3):175-83.

18. Suomela S, Kariniemi A-L, Impola U, Karvonen S-L, Snellman E, Uurasmaa T, et al. Matrix metalloproteinase-19 is expressed by keratinocytes in psoriasis. Acta dermato-venereologica. 2003;83(2):108-14.
19. Sekhon BS. Matrix metalloproteinases-an overview. Res Rep Biol. 2010;1:1-20.

20. Bell J, McQueen D, Rees J. Involvement of histamine $\mathrm{H} 4$ and $\mathrm{H} 1$ receptors in scratching induced by histamine receptor agonists in BalbC mice. British journal of pharmacology. 2004;142(2):374-80.

21. Gutgesell C, Heise S, Seubert A, Stichtenoth D, Frölich J, Neumann C. Comparison of different activity parameters in atopic dermatitis: correlation with clinical scores. British Journal of Dermatology. 2002;147(5):914-9.

22. Schon MP. Inhibitors of selectin functions in the treatment of inflammatory skin disorders. Ther Clin Risk Manag. 2005;1(3):201-8.

23. Ghazanfari T, Faghihzadeh S, Aragizadeh H, Soroush MR, Yaraee R, Mohammad Hassan Z, et al. Sardasht-Iran cohort study of chemical warfare victims: design and methods. Arch Iran Med. 2009;12(1):5-14.

24. Brew K, Nagase H. The tissue inhibitors of metalloproteinases (TIMPs): an ancient family with structural and functional diversity. Biochimica et Biophysica Acta (BBA)-Molecular Cell Research. 2010;1803(1):55-71.

25. Cawston T. Metalloproteinase inhibitors and the prevention of connective tissue breakdown. Pharmacology \& therapeutics. 1996;70(3):163-82.

26. Johnson LL, Dyer R, Hupe DJ. Matrix metalloproteinases. Current opinion in chemical biology. 1998;2(4):466-71.

27. Shohrati M, Haji Hosseini R, Esfandiari MA, Najafian N, Najafian B, Golbedagh A. Serum matrix metalloproteinase levels in patients exposed to sulfur mustard. Iran Red Crescent Med J. 2014;16(3):e15129.

28. Shohrati M, Ahmadi M, Esfandiari MA, Soleimani N, Davari SM, Najafian B. Level of matrix metalloproteinases and their inhibitors in skin tissue samples of sulfur mustard exposed chemical patients. Trauma Monthly. 2011;2011(3, Autumn):163-7.

29. Shakarjian MP, Bhatt $P$, Gordon MK, Chang YC, Casbohm SL, Rudge TL, et al. Preferential expression of matrix metalloproteinase- 9 in mouse skin after sulfur mustard exposure. J Appl Toxicol. 2006;26(3):239-46.

30. Zebrowska A, Wagrowska-Danilewicz M, Danilewicz M, Stasikowska-Kanicka O, KulczyckaSiennicka L, Wozniacka A, et al. Mediators of mast cells in bullous pemphigoid and dermatitis herpetiformis. Mediators Inflamm. 2014;2014:936545.

31. Tengara S, Tominaga M, Kamo A, Taneda K, Negi O, Ogawa H, et al. Keratinocyte-derived anosmin1 , an extracellular glycoprotein encoded by the $\mathrm{X}$ linked Kallmann syndrome gene, is involved in modulation of epidermal nerve density in atopic 
dermatitis. Journal of dermatological science. 2010;58(1):64-71.

32. Tominaga M, Takamori K. Recent advances in pathophysiological mechanisms of itch. 2010.

33. Tominaga M, Kamo A, Tengara S, Ogawa H, Takamori K. In vitro model for penetration of sensory nerve fibres on a Matrigel basement membrane: implications for possible application to intractable pruritus. British Journal of Dermatology. 2009;161(5):1028-37.

34. Asaduzzaman M, Rahman M, Jeppsson B, Thorlacius H. P-selectin glycoprotein-ligand-1 regulates pulmonary recruitment of neutrophils in a platelet-independent manner in abdominal sepsis. British journal of pharmacology. 2009;156(2):307-15.

35. Hayashi S, Abe Ky, Matsuoka H, Goya S, Morishita H, Mori M, et al. Increased level of soluble E-selectin in the serum from patients with idiopathic pulmonary fibrosis. Inflammation. 2004;28(1):1-5.

36. Hall RP, 3rd, Takeuchi F, Benbenisty KM, Streilein RD. Cutaneous endothelial cell activation in normal skin of patients with dermatitis herpetiformis associated with increased serum levels of IL-8, sESelectin, and TNF-alpha. $\mathrm{J}$ Invest Dermatol. 2006;126(6):1331-7.
37. Thestrup-Pedersen K, Ring J. Atopic Dermatitis. Summary of the $1 \mathrm{st}$ Georg Rajka Symposium 1998 and a Literature Review. Acta Dermatovenereologica-Stockholm-. 1999;79:257-64.

38. Barker J, editor. Adhesion molecules in cutaneous inflammation. Ciba Found Symp; 1995.

39. Cordero MM, Casas BB, Reyes RN, Avila CL, del Río NB, Sienra MJ. [Cyclosporin A in atopic dermatitis]. Revista alergia Mexico (Tecamachalco, Puebla, Mexico: 1993). 2001;49(4):129-34.

40. Shimada Y, Sato S, Hasegawa M, Tedder TF, Takehara K. Elevated serum L-selectin levels and abnormal regulation of $\mathrm{L}$-selectin expression on leukocytes in atopic dermatitis: soluble L-selectin levels indicate disease severity. Journal of allergy and clinical immunology. 1999;104(1):163-8.

41. Nakamura M, Toyoda M, Morohashi M. Pruritogenic mediators in psoriasis vulgaris: comparative evaluation of itch-associated cutaneous factors. British Journal of Dermatology. 2003;149(4):718-30.

42. Kneuer C, Ehrhardt C, Radomski MW, Bakowsky U. Selectins-potential pharmacological targets? Drug discovery today. 2006;11(21):1034-40.

\section{How to Cite This Article:}

Askari N, Ghazanfari T, Naghizadeh MM, Moin A, Khamesipour A, Pourfarzam S, et al. Evaluation of Association Between the Serum Levels of MMP-9 and MMP-9/TIMPs With Soluble Forms of Selectins and Itching Induced by Sulfur Mustard. Iran J Pathol. 2017;12(3):257-264. 